This item was submitted to Loughborough's Research Repository by the author.

Items in Figshare are protected by copyright, with all rights reserved, unless otherwise indicated.

\title{
Explaining variability in the investment location choices of MNEs: an exploration of country, industry and firm effects
}

\section{PLEASE CITE THE PUBLISHED VERSION}

http://dx.doi.org/10.1016/j.ibusrev.2016.12.002

\section{PUBLISHER}

(c) Elsevier

\section{VERSION}

AM (Accepted Manuscript)

\section{PUBLISHER STATEMENT}

This work is made available according to the conditions of the Creative Commons Attribution-NonCommercialNoDerivatives 4.0 International (CC BY-NC-ND 4.0) licence. Full details of this licence are available at: https://creativecommons.org/licenses/by-nc-nd/4.0/

\section{LICENCE}

CC BY-NC-ND 4.0

\section{REPOSITORY RECORD}

Rasciute, Simona, and Paul Downward. 2016. "Explaining Variability in the Investment Location Choices of Mnes: An Exploration of Country, Industry and Firm Effects". Loughborough University. https://hdl.handle.net/2134/23525. 
Explaining variability in the investment location choices of MNEs: An exploration of country, industry and firm effects

\author{
Dr Simona Rasciute \\ School of Business and Economics \\ Loughborough University \\ Leicestershire \\ LE11 3TU \\ UK \\ s.rasciute@lboro.ac.uk \\ +441509223620
}

Professor Paul Downward

School of Sport, Exercise and Health Sciences

Loughborough University

Leicestershire

LE11 3TU

UK

p.downward@lboro.ac.uk +441509226365

\section{Short Running Title:}

Multinational Enterprise Location Choice 


\title{
Explaining variability in the investment location choices of MNEs: An exploration of country, industry and firm effects
}

\begin{abstract}
This paper examines the variation in foreign direct investment (FDI) location decisions of European multinational enterprises (MNEs.) An innovative empirical approach is applied to a new data set which contains over 15,000 individual FDI location decisions in 25 European countries over a 17-year period and combines country, industry and firm level factors. The empirical results show that the responsiveness of FDI location choices to country-level factors is heterogeneous both across sectors and across firms of different characteristics as well as unobserved factors. In particular the results show that the importance of the market size, good infrastructure and Western business and legal environment increases with investing firm's size, while proximity, as well as cultural and linguistic ties are more important for smaller firms.
\end{abstract}

Keywords: Logistic Regression, Heterogeneity, Theories of FDI and the MNE, European Union, Foreign Direct Investment 


\section{Introduction}

Multinational enterprises face a number of major decisions while undertaking foreign activities. Firstly, they have to decide whether to produce at home and export, or whether to produce abroad (Helpman et al., 2004). Conditional on locating production abroad the firm then has a second choice among alternative locations of production (Rasciute et al., 2014b). Thirdly, the MNE has to choose a mode-of-entry (Brouthers, 2002; Boech and Beamish, 2012; Arslan et al., 2015; Hernández and Nieto, 2015). Finally, conditional on deciding the entry mode and where to locate, the firm has to decide on the scale of investment (Sethi et al., 2003; Kang and Jiang, 2012; Anderson and Sutherland, 2015). The existing literature on FDI mainly analyses the first and the last two choices by assessing: why do some firms only serve the domestic market, while others also export or serve foreign markets through a subsidiary?; how do firms enter these foreign markets and how much do firms invest? There is still a lack of detailed analysis of where firms choose to locate their investment. Of the studies that do attempt to investigate location choices of MNEs, most rely either on the Multinomial logit (MNL) or the Nested logit (NL) model. There are both technical and theoretical reasons why analyses using these models have limitations. In the first case, the MNL model, for example, is subject to restrictive assumptions regarding the substitution patterns across alternative investment locations ${ }^{1}$. In the second case, however, and of most importance for this paper, neither of these models allows for unobserved heterogeneity between investing firms, which is potentially very important for the choice of investment location as has been emphasized in the range of theoretical accounts of behavior in the international business (IB) literature. Sensitivity of foreign investors to some country level factors has been investigated across different industries (Jindra, et al. (2016), Carlton (1983), Javorcik (2004) and firm of different characteristics, such as size (Brouthers, et al., 1999), however, the exploration of unobserved heterogeneity is of much importance (Basile et al.,

\footnotetext{
${ }^{1}$ The NL model only partially relaxes the independence from irrelevant alternatives (IIA) assumption in order to allow some substitution across alternative investment locations.
} 
2008 and Rasciute et al., 2014a), as many firm characteristics are difficult to measure and quantify, such as the risk preferences of the investing firm's shareholders, the firm's ability to curb opportunistic behavior by its local partners (Filatotchev and Wright, 2011; Lien and Filatotchev, 2015), parent's ownership structure (Jones and Butler, 1992), intangible assets like patents, the capacity to innovate, superior production technique, and the systems for buying, producing and marketing, etc. These unobserved effects may have a further effect on the sensitivity of foreign investors to country-level factors and, therefore, need to be taken into account.

As a result, wedraw on Dunning's OLI paradigm, which then provides a basis for extending the existing analyses by explicitly allowing for two layers of unobserved heterogeneity in the investing firms' location decisions. This is undertaken for the first time by using the latent class random parameters (LCRP) model (Greene, 2012). This model explores how the effects of country-level factors on investment location decisions might vary according to different firm and industry observed characteristics through the class membership function, as well as unobserved heterogeneity through its latent class and random parameters components. The latent class component allows identifying different groups of investors that may respond differently to locational factors, while the random parameters component of the model then controls for any heterogeneity that remains within identified classes.

A further innovation of the paper is that we employ a new multi-level data set, combining country-, industry- and firm-level data over a 17-year period to examine individual firm FDI location decisions in Europe. By applying the LCRP model we seek to investigate how important the investing firm's and investment-receiving industry's characteristics, as well as unobserved heterogeneity, are in the choice of investment location and if alternative locations tend to attract different types of FDI, i.e. is the effect of location factors such as market size, transport costs and labour costs, among others, homogeneous across different investors like it has been mainly found in the existing empirical literature or does it vary 
depending on investing firm’s and investment-receiving industry’s characteristics as well as unobserved factors?

Our paper is set out as follows. Section 2 presents the theoretical framework and research hypotheses. Section 3 outlines the methodology. Section 4 presents the results and policy implications. Finally, Section 5 concludes.

\section{Literature Review and Research Hypotheses}

\subsection{Theoretical framework}

Although the origins of Dunning's eclectic paradigm can be traced back to the mid-1950s, the theory has evolved and continued gaining relevance in explaining the extent and pattern of international production, i.e. production financed by FDI and undertaken by MNEs (Dunning, 2001). The eclectic paradigm states that "the extent, geography and industrial composition of foreign production undertaken by MNEs is determined by the interaction of three sets of independent variables” that arise from three sub-paradigms (Dunning, 2000), based on ownership advantages (O), location advantages (L) and internalisation (I) (Dunning, 1993, 1998, 2001). Initially, the eclectic paradigm concentrated on static and efficiency related issues, and the I component was not added until later, when the theory evolved to address dynamic competitiveness and location strategy of firms (Dunning, 1998).

Ownership advantages are firm-specific competitive advantages that are created through a firm’s international experience, size, its ability to differentiate and adapt its product or service, as well as the service and technology intensity (Brouthers et al., 1996). Ownership specific advantages arise from the possession of such intangible assets as patents, the capacity to innovate, superior production technique, access to raw materials, cheap finance, and the systems for buying, producing and marketing. Ownership 
advantages have to be unique and sustainable to provide the firm with a competitive advantage (Brouthers et al., 1996).

Three main ownership specific advantages have been identified in the literature. The first is the ownership advantage arising from monopoly power, identified by Hymer (1976) who analyses MNEs as institutions of international production through the perspective of the industrial organisation theory. MNEs would emerge as a result of market imperfections by removing competition internationally in order to achieve monopolistic power (Dunning and Rugman, 1985). The second is the resource-based perspective, where rents arise from scarece and unique firms-specific assets and resources rather than through product market positioning (Teece et al., 1997). Most importantly to this paper, it follows from this resource-based approach that firms are heterogeneous with respect to their resources, capabilities and endowments (Teece et al., 1997). The third ownership advantage is related to 'dynamic capabilities', which refer to adapting, integrating and reconfiguring internal and external organisational skills, resources and functional competencies to adapt to rapidly changing environment (Teece et al., 1997).

Location advantages arise either from natural differences between countries, for example, differences in endowments of natural resources, differences in input, production and transport costs, or artificial differences, such as trade barriers, taxes and technical specifications, as well as cultural, political and legal differences. Location advantages are host market characteristics, such us market risk and potential demand. MNEs search for these location advantages to better harness their ownership advantage, however, some firms are better than others in harnessing these location advantages.

The internalisation advantage explains why it is more beneficial to exploit ownership and location advantages internally by setting up a subsidiary rather than licensing some other firm in the host country to produce the good, as firms need to balance the trade-off between the uncertainty of host country risk and the economies of scale in their host market expansion. The internalisation sub-paradigm allows 
"evaluating alternative ways in which firms may organise the creation and exploitation of their core competencies, given the location attraction of different countries or regions” (Dunning, 2000).

The eclectic paradigm goes further arguing that the significance of these three advantages and the interaction among them is likely to vary across countries, industries and firms (Dunning, 2001). Diversity or heterogeneity of firms and locational environments, as well as firm-location interactions matter (Cantwell, 2009). For example, Jindra, et al. (2016) show that home country effects differ for manufacturing versus service sectors. Carlton (1983) finds that the unemployment variable, which reflects the availability of unskilled labour force, is positive for the industry of Fabricated Plastic Products but it is negative for the industries of Communication Transmitting Equipment and Electronic Component. Javorcik (2004) finds that weak protection of intellectual property rights deters foreign investors in technology-intensive sectors, as it increases the probability of imitation, which erodes a firm's ownership advantages and decreases localization advantages of a host country.

Duanmu (2012) finds that Chinese State-Owned Enterprises (SOEs) are differently affected by host country’s political risk and exchange rates as compared to non-SOEs. Brouthers et al. (1999) find that larger multinational firms tend to use more integrated entry modes in low potential markets than small less experienced firms, which tend to use less-involved entry modes, like exporting or licensing, in high potential markets. Firms of different sizes and profitability possess different resources and capabilities. Small firms are assumed to be characterised by speed, flexibility and niche-filling capabilities due to their structural simplicity and faster decision making, entrepreneurial-orientation and less risk aversion (Woo 1987). As a result, smaller firms respond quicker to the dynamics of the industry environment, they are also less likely to be discouraged to invest in riskier environments. Larger firms, in contrast, are able to acquire larger market shares by exploiting scale economies, bargaining power, patents, reputation and they have more financial resources to deal with shocks and business downturns (Dean et al. 1998). 
The firm's FDI location decisions are influenced not only by location-specific attributes, the scale and skill requirements of different industries, and/or firm-specific characteristics but also by the risk preferences of the investing firm's shareholders and the firm's ability to curb opportunistic behavior by its local partners (Filatotchev and Wright, 2011; Lien and Filatotchev, 2015), as well as the parent's ownership structure (Jones and Butler, 1992). The latter factors are difficult to observe and measure, reinforcing the important of controlling for not only observed but also unobserved firm heterogeneity. Therefore, our hypotheses presented in the next section are augmented to incorporate differential firm and industry effects of country-level factors, which are then modelled through the class membership function of the LCRP model, while unobserved heterogeneity is captured by the latent class and random parameters components of the models. The LCRP model is developed in the next section.

\subsection{Hypotheses}

Drawing on Dunning's OLI paradigm discussed above we now present our research hypotheses on how industry and firm level differences, as well as unobserved firm heterogeneity, can influence the responsiveness to host country characteristics, when locating capital abroad.

Larger markets are attractive for investors generally, as they provide greater demand for goods and services as well as greater supply of inputs. Larger investing firms and firms investing in scale-intensive industries, however, benefit from larger markets to a greater extent, as larger markets mean more potential to exploit their economies of scale. It is therefore expected that:

H1a. Larger market size increases the probability of investment location choices and this effect is expected to be of most importance for larger investing firms.

H1b. Larger market size increase the probability of investment location choices and this effect is expected to be of most importance for firms investing in scale-intensive industries. 
Transaction costs of undertaking foreign activities, such as the costs of transport and communication, the costs of dealing with cultural differences, the costs of sending personnel abroad and the informational costs of institutional and legal factors are found to negatively affect the investment location choices of MNEs and these costs are all assumed to increase with distance. While distance is a continuous measure, a common border between investing and investment receiving country represents a discrete effect on costs of doing business abroad and, therefore, reduces distance (Beugelsdijk and Mudambi, 2013).

These costs are expected to be of more importance to smaller firms who prefer to invest in more proximate neighbouring countries with strong cultural and historical ties, while larger firms have bigger resources to cover higher transaction costs and they are not (as much) discouraged to locate their investment in more remote locations to access larger markets. When distance between a home and a host country becomes greater, this increases the uncertainty of doing business, which is especially critical for small ventures (Ojala, 2015). Unlike large established corporations, small organizations have limited resources for international experience (Oviatt \& McDougall, 1994) or for competitive advantages to be transformed in such a way as to overcome the difficulties created by distance dimensions (Nebus \& Chai, 2014). These arguments suggest that:

H2a. Higher transaction costs of undertaking foreign activities decrease the probability of investment location choices and this effect is expected to be of most importance for smaller investing firms.

H2b. A common border between investing and investment receiving country will increase the probability of investment location choices and this effect is expected to be of most importance for smaller investing firms.

The profitability of the firm investing abroad is expected to be higher if the labour costs are lower in the chosen country than in the rest of the destination countries (Barrell and Pain 1999). On the other hand, higher wages may reflect higher skills and, therefore, may have a less negative or even positive effect for 
firms investing in science-based industries, where more skilled labour is employed as compared to other industries. This suggests that:

H3. Higher labour costs in the host country reduces the probability of investment location choices but less so for firms investing in science-based industries.

It is not only labour costs, however, but also the availability of labour force that is of importance for potential investors. Countries with high local demand for goods and services and high labour market flexibility are likely to face relatively low rates of unemployment, which may encourage firms to invest in a particular host country. On the other hand, a high unemployment rate may mean that it is easy to recruit labour. The impact of the availability of labour on the investment location decision may, therefore, have a different effect on firms investing in different industries. It can be concluded that the effect of labour force availability is related to skill, therefore, firms investing in traditional sectors employ less skilled labour and may be more concerned about the availability of workers, while firms investing in sciencebased industries, which employ more skilled labour, may be discouraged by higher unemployment, as unemployed people lose their skills through time. These arguments suggest:

H4. Countries with greater availability of labour force are more likely to be chosen by firms investing in traditional sectors.

The institutional, legal and political environment and effectiveness of legal system are important for the decision of foreign investors to locate their capital abroad. These factors are of greater importance for firms investing in technology-intensive sectors such as science-based industries that rely heavily on intellectual property rights (Javorcik, 2004). . Consequently it is proposed that:

H5. Higher risk in the host country reduces the probability of investment location choices and this effect is expected to be of most importance for firms investing in science-based industries. 
Countries that joined the EU in 2004, 2007 and 2013 had to satisfy the economic (market economy), political (democracy and human rights) and administrative (well-functioning institutions) criteria set at the Copenhagen European Council in 1993. The accession of a CEE country into EU meant free trade with EU member states and the adoption of Western business and legal environment, which provided foreign investors with confidence in success of each country's reforms. EU membership created a better environment for investors, especially for larger firms, as EU membership increased the size of markets into which foreign firms can sell, which enables them to reap economies of scale. Therefore, it is expected that:

H6a. EU membership of investing and investment receiving countries increases the probability of investment location choices and this effect is expected to be of most importance for larger investing firms.

H6b. EU membership of investing and investment receiving countries increases the probability of investment location choices and this effect is expected to be of most importance for firms investing in scale-intensive industries.

The hypotheses above refer to observed heterogeneity, i.e. the sensitivity of country-level factors to observed firm and industry characteristics, however, not all sources of heterogeneity may be initially directly observable and, therefore, hypothesised. The LCRP model allows taking into account unobserved heterogeneity through its latent class and random parameters components, which is discussed in the following section. Initially, the latent classes may not be well-defined and the number of classes and their characterisation is not known until an "exploratory” data analysis. Unobserved heterogeneity is revealed by further sensitivity of country-level factors across different latent classes and further variation in the parameters of some country level factors within each class. 


\section{Methodology}

\subsection{Sample and Data}

Our dataset contains variables at country, industry and firm level and the data are drawn for different sources. The firm and industry-level data, including the decision where to locate investment, come from the Bureau van Dijk Zephyr dataset. Country-level data have been obtained from IMF International Financial Statistics and Eurostat. Our sample consists of 15,795 firm-level data observations on brownfield FDI location choices by firms of EU15 countries (except for Luxembourg) to firms in other EU15 countries and 11 new EU member states (Bulgaria, Czech Republic, Estonia, Croatia, Hungary, Lithuania, Latvia, Romania, Slovenia and Slovakia but not Malta and Cyprus) from 1997 to 2013. Only some of the firms (12\%) have invested more than once over the period and for most of the firms the investment location decision is a one-shot event.

In our sample, EU15 member states have received the largest share of the number of foreign capital allocations by MNEs (about 86 percent) with the UK receiving the largest share of the FDI allocations (about 14 percent) out of all the EU15 countries, followed by Germany with about 13 percent of foreign capital allocations. Among the new EU member states, Poland has received the largest share of FDI allocations (23 percent), followed by the Czech Republic with 15 percent of foreign investment location choices.

Service sectors seem to have received the largest number of foreign capital allocation in both regions (61 percent in EU15 and 60 percent in the new EU member states). Science-based industries, on the other hand, have received the smallest share of FDI (approximately 6 percent in EU15 and 4 percent in the new EU member states) in the sample. 


\subsection{Variable and Measures}

Our dependent variable takes the value of ' 1 ' if the country has been chosen as an investment location and ' 0 ' otherwise. Our explanatory variables presented in Table 1, are based on the hypotheses noted above, and are measured as follows: the market size (Hypothesis 1a and b) is measured as the real GDP of the host country. The transaction costs of undertaking foreign activities (Hypothesis 2a) are proxied by the distance between the capital cities of the investing and the investment receiving countries. It is obtained from www.indo.com and is calculated 'as the crow flies'. A dummy variable is constructed to take the value of 1 if investing and investment receiving countries share a common border and zero otherwise (Hypothesis 2b).

Insert Table 1 here

Availability of the labour force (Hypothesis 4) is measured by the unemployment rate which is calculated as a percentage by dividing the number of unemployed individuals by all individuals currently in the labor force. Labour costs (Hypothesis 3) are included as a measure of the average variable costs of firms and they are proxied by hourly wages in manufacturing in Euros but adjusted for the purchasing power standard.

Risk of locating capital abroad (Hypothesis 5) is captured by the Transparency International Corruption Perception Index (TICP), which is used as a measure of the extent of corrupt practices in the host country. It ranks countries in terms of the degree to which corruption is perceived to exist among public officials and politicians and it varies from 1 (high corruption) to 10 (no corruption). A dummy variable for EU membership (Hypothesis 6a and 6b) has been constructed to take the value of 1 if both investing and investment receiving countries were both EU members at the time of investment and 0 otherwise. 
Tax systems are extremely complex and the statutory corporate income tax rate does not capture the total tax burden. As a result, the effective corporate income tax rate is calculated by dividing taxes on the income or profits of corporations including holding gains by the respective host country’s GDP. Our approach allows comparisons of different national tax systems, taking into account such important aspects as untaxed reserves, tax enforcement and the treatment of losses.

As it is expected that firms investing in different industries and firms of different characteristics respond to country-level factors to a different degree, the industries that have received foreign capital have been divided into four groups to best reflect the scale and skill intensity: scale-intensive sectors, science-based industries, traditional sectors and service sectors. Table 2 provides a detailed breakdown of the specific industries in each group. Scale-intensive sectors are typically oligopolistic, large firm industries with high capital intensity, extensive economies of scale and learning, high technical and managerial complexity. Science-based sectors, on the other hand, are characterised by innovative activities directly linked to high R\&D expenditures (Midelfart-Knarvik et al. 2000). Traditional (supplier-dominated) sectors include such industries as textiles, clothing, furniture, leather and shoes, ceramics, and the simplest metal products. Finally, banking insurance and retail are examples of service sector industries.

Insert Table 2 here

Finally, the investing firm's size is measured by the number of its employees, while profitability by its earnings before tax. Table 3 summarises all the variables used in the analysis. This includes the countrylevel variables, as well as investment-receiving industry dummies and investing firm characteristics. Descriptive statistics for these variables include means, standard deviations, as well as minimum and maximum values. The means for the dummy variables give the sample proportions of the category measured as ' 1 ' but the standard deviations don't have much explanatory power. 
Insert Table 3 here

\subsection{Analysis}

The LCRP model is a form of multinomial model that combines the latent class model with the random parameters model in order to accommodate two layers of unobserved heterogeneity. The latent class aspect of the model implicitly divides investing firms into a number of classes, $Q$, while the random parameters aspect of the model specifies a continuous distribution of model parameters within each class (Greene, 2012). Following Greene (2012), the latent class structure can be specified as the following:

$$
\begin{gathered}
\operatorname{Prob}\left(\text { choice }_{i} \mid x_{i}, \text { class }=q\right)=g\left(y_{i} \mid x_{i}, \beta_{q}\right) \\
\operatorname{Prob}(\operatorname{class}=q)=\pi_{q}(\theta), \quad q=1, \ldots, Q
\end{gathered}
$$

Equation 2 indicates the probability that an investing firm is a member of a particular class based on its characteristics such as size, profitability, and the scale and skill intensity of the investment receiving industry as well as unobserved firm and industry characteristics, which are difficult to measure, such as intangible assets like patents, the capacity to innovate, superior production technique, and the systems for buying, producing and marketing. While the observed heterogeneity component is modelled by including firm and industry characteristics into the class membership function, following the hypothesis outlined in Section 2.2, the unobserved component of the the latent classes, initially, may not be well-defined and the actual number of latent classes and their characterisation may not be known until an "exploratory” data analysis, where each latent class reveals further sensitivity to country-level factors in addition to the sensitivity to observed firm and industry characteristic and further groupings of firms emerge. The difference in sensitivity to country-level factors in different latent classes is then due to firm and industry characteristics included into the class membership function as well as unobserved heterogeneity. Each 
class thus represents a certain type of investor who benefits from host country factors to different degrees. Equation 1 then describes the choice of country by the investing firm conditional on the membership of the class. This latter behaviour is a function of host country characteristics $x_{i}$.

The LCRP model then accommodates further unobserved heterogeneity within classes, as there may be further variation in the sensitivity to some country level factors within each class, by allowing for the continuous variation of the parameters within classes. In the random parameter aspect of the model, the within-class heterogeneity can be derived as the following:

$$
\begin{aligned}
& \beta_{i \mid q}=\beta_{q}+w_{\beta_{i \mid q}} \\
& w_{\beta_{i \mid q}} \sim E\left[w_{\beta_{i \mid q}} \mid X\right]=0, \quad \operatorname{Var}\left[w_{\beta_{i \mid q}} \mid X\right]=\sum_{q}
\end{aligned}
$$

where parameters in a class ' $q$ ' vary randomly according to $w_{\beta_{i \mid q}}$ which is uncorrelated with all of the exogenous data in the sample.

\section{Results}

For robustness reasons, our analysis initially reports the association of country-level variables with the FDI location choices of MNEs from estimating a Conditional Logit (CL) model. This provides an initial check on the relevance of the data to the location decision. The results are presented in Table 4, column 2. The direction and the statistical significance of these host country characteristics are in line with the existing literature. Market size has a positive and statistically significant association with the probability of firms locating foreign capital. Transport costs, on the other hand, are negatively related to the FDI location choices of MNEs, while common border has a positive effect. The labour costs have a 
statistically significant and negative effect on the probability of locating capital abroad. Unemployment in the host country is positively associated with investment location choices of MNEs indicating that foreign firms look for a pool of workers when they locate their capital abroad. Interestingly, the tax variable is positively associated with the decision of where MNEs locate their investment, which indicates that higher taxes may serve as a signal for investing firms of better services and infrastructure in the host country. The extent of corrupt practices among politicians and public officials in the host country is negatively associated with investment location decisions of MNEs. ${ }^{2}$ Finally, the EU dummy has a positive effect on the probability of locating capital abroad.

As indicated earlier, however, these results are likely to hide heterogeneous behaviour, as firms of different characteristics and firms investing in different sectors may be affected by country-level factors to a different extent. As a result, to capture the observed heterogeneity, a CL mode with interaction terms between country-level variables and firm and industry characteristics are estimated (Table 4, Column 3). The significance and signs of the separate country-level variable parameters are the same as in the previous CL model, however, in addition a number of interaction terms appear to be statistically significant. The statistically significant interaction terms between host country market size and the size of the investing firm as well as the dummy for scale-intensive industry indicate that larger investing firms and firms investing in scale-intensive industries benefit from larger markets to a greater extent as compared to smaller firms and firms investing in traditional sectors, science-based sectors and service sectors, as larger markets mean more potential to exploit their economies of scale. Statistically significant interaction terms between investing frim size and transaction costs as well as the dummy for common border between investing and investment receiving country indicate that smaller firms tend to invest in more proximate neighbouring countries with strong cultural and historical ties, while larger firms have

\footnotetext{
${ }^{2}$ Although the sign of the estimated parameter of the Risk variables is positive, the relationship between the investment locations decisions and the extent of corrupt practices within the host country is negative, as the variable is coded in the way that it varies from 1 (high corruption) to 10 (no corruption).
} 
bigger resources to cover higher transaction costs. Statistically significant interaction term between the unemployment rate in the host country and the dummy variable for traditional sectors indicates that industries that employ more unskilled labour prefer countries with higher unemployment rates, which indicate a larger pool of unskilled workers, as unemployed people may lose their skills through time. Finally, statistically significant interaction term between the risk in the host country and the dummy for science-based industries indicate that firms investing in technology-intensive sectors prefer more stable environment and better intellectual property right protection.

Finally, to also capture unobserved heterogeneity, the LCRP model is estimated and the results are presented in Table 4, Columns 4. The fit of the model, indicated by the Log-Likelihood function and Pseudo R-squared is considerably better for the LCRP model as compared to both the CL models implying the superiority of the LCRP model.

Insert Table 4 here

The results in the ‘Class Membership’ part of Table 3 show that the latent class aspect of the model divides investing firms into three classes ${ }^{3}$, where their membership is shown not only to be determined by unobserved heterogeneity but also by investing firms' size, the scale intensity of the investment-receiving industry as well as a dummy for traditional sectors ${ }^{4}$. Around 31 percent of the firms are allocated into Class 1, 34 percent into Class 2 and 35 percent into Class 3. These estimated class membership parameters show that Class 1 is more likely to contain small firms, which are more likely to invest in nontraditional sectors, while Class 2 is more likely to include large firms locating their investment in scale-

\footnotetext{
${ }^{3}$ The choice of three latent classes is supported by formal tests, i.e. AIC and BIC criteria, as well as, the rule of thumb, where with more than three classes the standard errors of the estimated coefficients become large and the class membership probability for at least one class becomes relatively small.

${ }^{4}$ The rest of the investing firm and investment-receiving industry characteristics do not seem to be statistically significant.
} 
intensive but non-traditional industries. In Class 3 the parameters of investing firm-specific variables are normalised as their values are set to zero and the class serves as a base class relative to Classes 1 and 2 and is thus more likely to contain medium-size MNEs that locate their investment in non-scale-intensive industries, which are traditional sectors.

The estimated parameters (random and non-random) for all the variables in each latent class (Table 4, upper half of Column 4) show how investment location decisions of MNEs are affected by various country-level factors. The standard deviations of the random parameters for unemployment and tax variables then capture further heterogeneous behaviour within each class, which is not displayed for the rest of the variables as their standard deviations are not statistically significant. These results reveal that the three groups of heterogeneous investing firms benefit from country-level factors differently.

The magnitudes of the estimated parameter are, however, not comparable across the latent classes due to scale differences. As investing firms in all the three latent classes are positively affected by the host country market size, the importance of the effects for this variable across the classes can only be implied from the t-statistics in Table 3, which are the highest in Class 2, indicating that market size is of most importance for investing firms in Class 2. Class 2 contains larger investors who are more likely to invest in scale-intensive non-traditional industries and hence they may locate their capital abroad to access foreign markets in order to exploit their economies of scale, showing support for Hypotheses 1a and 1b. These firms, however, are not discouraged from locating their investment in more remote (not necessarily neighbouring) countries to access these markets (the transport cost variable is positively associated with the FDI location decisions of MNEs and common border dummy is not statistically significant in Class 2). Distance, on the other hand, is negatively associated and common border is positively associated with the investment location decisions of MNEs in Classes 1 and 3, which contain small and medium-size MNEs respectively (Table 4), showing further support for Hypotheses 2a and 2b. Small firms are, 
therefore, more likely to locate their investment in more proximate neighbouring countries with strong cultural and historical ties.

We also find support for Hypothesis 3, as wages appear to be statistically significant for investors in all the three classes. The variable has a positive effect for investors in Class 1 but a negative effect for investors in Class 2 and 3. Class 2 and 3 are more likely to contain investors locating their capital in scale-intensive industries and traditional sectors, respectively, which tend to employ less-skilled labour as compared to other industries, such as science-based sectors. On the other hand, wages appear to have statistically significant and positive effect for firms in Class 1, which contains smaller investors who locate their capital in non-traditional sectors, possibly science-based industries. Higher wages do not only indicate higher cost and, consequently, lower potential profits for investing firms, but also higher productivity, which may counterbalance the former negative effect and be of more importance for firms investing in science-based industries.

We do not find support for Hypothesis 4, as the unemployment rate is significant to the investors in Classes 1 and 2 and it is positively related to the FDI location decisions, as investing firms in these two classes look for a larger pool of workers.

Higher risk in the host country reduces the probability of investment location choices for small firms investing in non-traditional sectors, possibly science-based industries (supporting Hypothesis 5). The institutional, legal and political environment and effectiveness of legal system are especially important for foreign investors to locate their capital in technology-intensive sectors. We also find support for Hypotheses 6a and 6b, as the results show that large firms investing in scale-intensive industries (Class 2) are more likely to locate their investment in countries that are EU members. EU membership implies the adoption of a Western business and legal environment and free trade, which in turn increased the size of markets into which foreign firms can sell, allowing them to reap economies of scale. 
Firms in all the three classes are positively affected by the tax variable. This might be explained by the fact that larger tax income is translated into better services and infrastructure in the host country.

In summary, the importance of the market size becomes more important for larger investors, who locate their capital in scale-intensive industries, while proximity as well as cultural and historical ties appear to be more important for smaller firms.

Finally, while the latent class part of the model estimates the parameters for each class, capturing the mean effect of the variables on the decision to locate foreign investment, the random parameters aspect of the main model, also includes the standard deviation for the unemployment and tax variables, and controls for an additional layer of heterogeneity within each class. ${ }^{5}$ The statistically significant standard deviations noted are for the unemployment and tax variables and they indicate that there is potential further within-class heterogeneity for the two variables and their effects cannot just be captured by the mean value of the parameter. As such they control for further unobserved heterogeneity. This offers interesting policy implications, as by restricting the mean of the triangular distribution for the two variables to be equal to its standard deviation reveals that the sign of the estimated random parameters of the two variables is the same for all the investing firms. Consequently, although there is further within-

\footnotetext{
${ }^{5}$ There are no rules that help in the choice of the appropriate distribution to estimate the random parameters within each class apart from the requirement that the mean and standard deviation of the random parameter be statistically significant. As a result, the analysis starts by treating each coefficient of the country-level variables separately as random by imposing various distributions, which gives an indication of which distribution should be used for random parameters when they are combined in the final specification. The statistically significant standard deviations noted are for the restricted triangular distribution for the unemployment and tax variables.
} 
class variation for some country-level factors, the direction of the two effects is the same for all the firms in the same latent class.

Overall our results show that using the LCRP model allows much more flexibility and gives better model fit than the CL model, as it accounts for two layers of investing firms' heterogeneity. This is important because, for example, while the distance variable is negative and statistically significant for the CL model, which is also broadly found in the literature, the LCRP model shows that the transport costs may be positive and negative depending on observed and unobserved investing firm heterogeneity. Consequently, country-level factors do not affect investment locations choices of MNEs in a uniform way, as firms of different observed and unobserved characterises and firms investing in different sectors respond to country-level factors differently. This is a result that has not been established in the literature before.

\section{Conclusions}

This study contributes to the international business literature in several ways. First, it applies the Latent Class Random Parameters (LCRP) model to investigate the investment location choices of MNEs in Europe. Secondly, it makes use of a novel multi-level data set - allowing firm, industry (or sector) and country effects to simultaneously determine the firm-level FDI location decisions. The significant empirical results support the presence of observed and unobserved heterogeneity in the investment location decisions, which is revealed by statistically significant class-specific parameters as well as standard deviations of some of the parameters. The model reveals three classes of foreign investors depending on investment receiving industry and country factors, investing firms’ individual characteristics and latent heterogeneity that varies with factors that are unobserved. The estimation results overall show that the importance of the market size increases with investing firm's size and scale, while proximity, as well as cultural and linguistic ties are more important for smaller firms. 
Governments in different countries compete to attract foreign direct investment, as some multinational corporations often bring new technologies, management skills and marketing know-how. In order to create an investment friendly environment, it is important to understand the factors that influence different types of investors as well as their variable sensitivity to the determinants of FDI locations decisions. 
Table 1: List of variables, definitions and sources

\begin{tabular}{|c|c|c|}
\hline Variable & Definition & Source \\
\hline Choice & $\begin{array}{l}\text { An EU country in which a firm from EU15 chooses to } \\
\text { locate its investment over the period of time from } \\
1997 \text { to } 2013 \text { (it gets the value of } 1 \text { if the country } \\
\text { received investment and } 0 \text { otherwise) }\end{array}$ & Bureau van Dijk Zephyr database \\
\hline Msize & $\begin{array}{l}\text { Real GDP of the host country of the year investment } \\
\text { took place }\end{array}$ & $\begin{array}{l}\text { IMF (International } \\
\text { Statistics) }\end{array}$ \\
\hline Unempl & $\begin{array}{l}\text { unemployment rate of the host country (percentage } \\
\text { per annum) of the year investment took place }\end{array}$ & $\begin{array}{l}\text { IMF (International } \\
\text { Statistics) }\end{array}$ \\
\hline Dist & $\begin{array}{l}\text { distance in kilometres between the capital cities of the } \\
\text { host and the home countries }\end{array}$ & www.indo.com \\
\hline Border & $\begin{array}{l}1 \text { if investing and investment receiving countries } \\
\text { share a common border and } 0 \text { otherwise. }\end{array}$ & \\
\hline Wage & $\begin{array}{l}\text { Hourly wages in manufacturing in Euros but adjusted } \\
\text { for the purchasing power standard }\end{array}$ & Eurostat \\
\hline Risk & varies from 1 (high corruption) to 10 (no corruption) & Transparency International \\
\hline $\mathbf{E U}$ & $\begin{array}{l}1 \text { if both investing and investment receiving countries } \\
\text { are EU members at the time of investment and } 0 \\
\text { otherwise }\end{array}$ & \\
\hline Tax & $\begin{array}{l}\text { The ratio between taxes on the income or profits of } \\
\text { corporations including holding gains and the } \\
\text { respective host country's GDP of the year investment } \\
\text { took place }\end{array}$ & $\begin{array}{l}\text { IMF (International Financial } \\
\text { Statistics) }\end{array}$ \\
\hline Science & $\begin{array}{l}1 \text { if investment-receiving industry is science-based } \\
\text { industry, and } 0 \text { otherwise }\end{array}$ & Bureau van Dijk Zephyr database \\
\hline Scale & $\begin{array}{l}1 \text { if investment-receiving industry is scale-intensive } \\
\text { industry, and } 0 \text { otherwise }\end{array}$ & Bureau van Dijk Zephyr database \\
\hline Tradit & $\begin{array}{l}1 \text { if investment-receiving industry is traditional } \\
\text { industry, and } 0 \text { otherwise }\end{array}$ & Bureau van Dijk Zephyr database \\
\hline Services & $\begin{array}{l}1 \text { if investment-receiving industry is service sector, } \\
\text { and } 0 \text { otherwise }\end{array}$ & Bureau van Dijk Zephyr database \\
\hline FSize & $\begin{array}{l}\text { Number of employees in the investing firm of the year } \\
\text { investment took place }\end{array}$ & Bureau van Dijk Zephyr database \\
\hline Profit & $\begin{array}{l}\text { Investing firm's earnings before tax in real terms of } \\
\text { the year investment took place }\end{array}$ & Bureau van Dijk Zephyr database \\
\hline
\end{tabular}


Table 2: The Allocation of Industries into Groups

\begin{tabular}{|c|c|}
\hline Industry group & Industries \\
\hline Scale-intensive & $\begin{array}{l}\text { Mining (coal, diamonds and gemstones, general mining, gold } \\
\text { mining, platinum and precious metals) } \\
\text { Oil and gas producers; oil equipment, services and distribution } \\
\text { Forestry and paper } \\
\text { Chemicals (commodity chemicals and specialty chemicals) } \\
\text { Industrial metals (aluminum, nonferrous metals and steel) } \\
\text { Industrial engineering (commercial vehicles and trucks; industrial } \\
\text { machinery); automobiles and parts } \\
\text { Utilities (Electricity; gas, water and multiutilities) }\end{array}$ \\
\hline $\begin{array}{l}\text { Traditional (supplier- } \\
\text { dominated) }\end{array}$ & $\begin{array}{l}\text { Food and beverages (brewers; distillers and vintners; soft drinks; } \\
\text { farming and fishing; food products); tobacco } \\
\text { Personal goods (clothing and accessories; footwear; personal } \\
\text { products) } \\
\text { Household goods (durable household goods; nondurable } \\
\text { household products; furnishings) } \\
\text { Containers and packaging; diversified industries } \\
\text { Construction and materials (building materials and fixtures; heavy } \\
\text { construction) }\end{array}$ \\
\hline Services & $\begin{array}{l}\text { Media (broadcasting and entertainment; media agencies; } \\
\text { publishing) } \\
\text { Retail ( Food and drug retailers; general retailers) } \\
\text { Travel and leisure (airlines; gambling; hotels; recreational } \\
\text { services; restaurants and bars; travel and tourism) } \\
\text { Industrial transportation (Delivery services; marine transportation; } \\
\text { railroads; transportation services; trucking) } \\
\text { Financials (banks; insurance); financial services (real estates; } \\
\text { general financials; investment instruments) }\end{array}$ \\
\hline Science-based & $\begin{array}{l}\text { Electronic and electrical equipment (electrical components and } \\
\text { equipment; electronic equipment); leisure goods ( consumer } \\
\text { electronics; recreational products and personal products); } \\
\text { telecommunications (telecommunications; fixed line } \\
\text { telecommunications; mobile telecommunications); technology } \\
\text { (software and computer services; technology hardware and } \\
\text { equipment) } \\
\text { Healthcare (healthcare equipment and services; pharmaceuticals } \\
\text { and biotechnology) }\end{array}$ \\
\hline
\end{tabular}


Table 3: Descriptive Statistics

\begin{tabular}{lcccc} 
Variable & Mean & Std.Dev. & Minimum & Maximum \\
\hline Rsik & 6.164992 & 2.047854 & 2.6 & 10 \\
Tax & 2.718717 & 0.81645 & 0.5 & 5.9 \\
EU & 0.800165 & 0.399877 & 0 & 1 \\
Border & 0.113783 & 0.317548 & 0 & 1 \\
Dist & 1233.567 & 651.3158 & 0 & 3362 \\
Wage & 16.38624 & 9.07906 & 2.269559 & 39.30735 \\
Unemp & 9.116232 & 4.023072 & 3.1 & 27.5 \\
Fsize & 22516.03 & 68532.33 & 0 & 629135 \\
Scale & 0.182526 & 0.386278 & 0 & 1 \\
Tradit & 0.150934 & 0.357985 & 0 & 1 \\
Service & 0.606711 & 0.488481 & 0 & 1 \\
Science & 0.059829 & 0.23717 & 0 & 1 \\
GDP & 438.6438 & 635.0613 & 6.7733 & 2482.43
\end{tabular}


Table 4: The Estimated Coefficients of the CL and RPLC Models

\begin{tabular}{|c|c|c|c|c|c|c|c|c|c|c|}
\hline \multirow[b]{2}{*}{ Unempl } & \multicolumn{4}{|c|}{ Conditional Logit model } & \multicolumn{6}{|c|}{$\begin{array}{l}\text { Latent Class Random Parameters model } \\
\text { Random parameters } \\
\end{array}$} \\
\hline & $.03027^{* * *}$ & 10.41 & $.02452 * * *$ & 7.83 & $.04775^{* * *}$ & 6.22 & $.02670^{* * *}$ & 4.34 & -0.00559 & -0.79 \\
\hline Tax & $.17917^{* * *}$ & 11.78 & $.17552^{* * *}$ & 11.51 & $.07803^{* *}$ & 2.07 & $.16571^{* * *}$ & 4.29 & $.11387 * * *$ & 3.97 \\
\hline & & & & & \multicolumn{6}{|c|}{ Nonrandom parameters } \\
\hline Dist & $-.00051 * * *$ & -32.5 & $-.00055 * * *$ & -33.5 & $-.00064 * * *$ & -12.18 & $.00050^{* * *}$ & 6.34 & $-.00119 * * *$ & -16.37 \\
\hline MSize & $.00080 * * *$ & 67.84 & $.00076 * * *$ & 58.19 & $.00043 * * *$ & 10.39 & $.00183 * * *$ & 19.17 & $.00038 * * *$ & 6.68 \\
\hline Wage & $-.02045 * * *$ & -18.84 & $-.02076 * * *$ & -19.06 & $.01507 * * *$ & 3.18 & $-.04866 * * *$ & -11.65 & $-.03505 * * *$ & -10.59 \\
\hline Border & $.91201 * * *$ & 46.28 & $.95646 * * *$ & 45.75 & $1.48961^{* * *}$ & 21.08 & -0.11154 & -0.98 & $1.02292 * * *$ & 16.61 \\
\hline Risk & $.09353^{* * *}$ & 14.85 & $.08885^{* * *}$ & 13.8 & $.34563 * * *$ & 9.35 & $-.07174 * * *$ & -2.61 & -0.01685 & -0.7 \\
\hline EU & $.58853 * * *$ & 13.68 & $.59454 * * *$ & 13.79 & 11.7217 & 0.05 & $2.53972 * * *$ & 6.31 & -0.16683 & -1.43 \\
\hline Msize*Scale & & & $.21588 \mathrm{D}-06^{* * *}$ & 8.84 & & & & & & \\
\hline MSize*FSize & & & $0.0^{* *}$ & 1.99 & & & & & & \\
\hline Dist*Fsize & & & $0.0 * * *$ & 9.17 & & & & & & \\
\hline Border*Fsize & & & $-.17632 \mathrm{D}-05^{* * *}$ & -5.41 & & & & & & \\
\hline Unemp*Tradit & & & $.03507 * * *$ & 5.46 & & & & & & \\
\hline \multirow[t]{2}{*}{ Risk*Science } & & & $.08500 * * *$ & 4.08 & & & & & & \\
\hline & & & & & \multicolumn{6}{|c|}{ Std deviations or limits of random parameters } \\
\hline TsUempl & & & & & $.04775^{* * *}$ & 6.22 & $.02670 * * *$ & 4.34 & 0.00559 & 0.79 \\
\hline TsTax & & & & & $.07803^{* *}$ & 2.07 & $.16571^{* * *}$ & 4.29 & $.11387 * * *$ & 3.97 \\
\hline & & & & & \multicolumn{6}{|c|}{ Class membership } \\
\hline Constant & & & & & $.36879 * *$ & 2.1 & -0.17365 & -1.12 & \multicolumn{2}{|c|}{ Fixed parameters } \\
\hline FSize & & & & & $-.43685 \mathrm{D}-04^{* * *}$ & -5.78 & $12726 \mathrm{D}-05^{* * *}$ & 2.7 & \multicolumn{2}{|c|}{ Fixed parameters } \\
\hline Tradit & & & & & $-.82148 * * *$ & -5.05 & $-.23569 * *$ & -2.36 & \multicolumn{2}{|c|}{ Fixed parameters } \\
\hline Scale & & & & & 0.04604 & 0.31 & $.82302 * * *$ & 8.3 & \multicolumn{2}{|c|}{ Fixed parameters } \\
\hline Class probs & & & & & 0.312 & & 0.341 & & \multicolumn{2}{|c|}{0.347} \\
\hline $\begin{array}{l}\text { Log-likelihood } \\
\text { Pseudo R-sqr }\end{array}$ & \multicolumn{2}{|c|}{$\begin{array}{l}-42875.87746 \\
0.0265\end{array}$} & \multicolumn{2}{|c|}{$\begin{array}{l}-42730.57509 \\
0.0298\end{array}$} & \multicolumn{6}{|c|}{$\begin{array}{c}-42325.57938 \\
0.1675099\end{array}$} \\
\hline
\end{tabular}




\section{References}

Alc"cer, J., Dezs , C.L. and Zhao, M. (2013). Firm rivalry, knowledge accumulation, and MNE location choices, Journal of International Business Studies, 44: 504-520.

Aliber, R. Z. (1970) A theory of direct foreign investment in C. P. Kindleberger (ed.) pp 17-34, The International Firm. Cambridge, Mass: MIT Press.

Anderson, J.E. and van Wincoop, E. (2003) Gravity with Gravitas: A Solution to the Border Puzzle, American Economic Review, 93(1):170-192.

Arslan, A. Tarba, S.Y. and Larimo J. (2015). FDI entry strategies and the impacts of economic freedom distance: Evidence from Nordic FDIs in transitional periphery of CIS and SEE. International Business Review, 24: 997-1008.

Bergstrand, J.H. (1985). The Gravity Equation in International Trade: Some Microeconomic Foundations and Empirical Evidence. The Review of Economics and Statistics, 67(3): 474481.

Barrell R., Pain N. (1999) Domestic institutions, agglomerations and foreign direct investment in Europe. European Economic Review 43: 925-934

Basile R, Castellani D, Zanfei A (2008) Location choices of multinational firms in Europe: The role of EU cohesion policy. Journal of International Economics 74: 328-340.

Beugelsdijk, S. and Mudambi, R. (2013). MNEs as border-crossing multi-location enterprises: the role of discontinuities in geographical space, Journal of International Business Studies, 44: 413426.

Boeh, K. K. and Beamish, P. W. (2012). Travel time and the liability of distance in foreign direct investment: Location choice and entry mode. Journal of International Business Studies, 43(5): $525-535$.

Brainard, S. L. (1993) A simple theory of multinational corporations and trade with a trade-off between proximity and concentration, NBER Working Paper No. 4269. 
Brainard, S. L. (1997). An empirical assessment of the proximity-concentration trade-off between multinational sales and trade, American Economic Review, 87 (4): 520-544.

Brouthers, L.E., Brouthers, K.D. and Werner, S. (1997). Dunning's eclectic theory and the small firm: the impact of ownership and location advantages on the choice entry modes in the computer software industry. International Business Review, 5(4): 377-394.

Brouthers, L.E., Brouthers, K.D. and Werner, S. (1999). Is Dunning’s eclectic framework descriptive or normative? Journal of International Business Studies, 30(4): 831-844.

Brouthers, K. D. (2002). Institutional, cultural and transaction cost influences on entry mode choice and performance. Journal of International Business Studies, 33(2): 203-221.

Carlton, D. W. (1983). The Location and Employment Choices of New Firms - an EconometricModel with Discrete and Continuous Endogenous Variables. Review of Economics and Statistics 65, 440-449.

Carr, D. L., Markusen, J. R., and Maskus, K. E. (2003). Estimating the knowledge-capital model of the multinational enterprise: Reply. American Economic Review 93, 995-1001.

Cosset, J-C. and Suret, J-M. (1995). Political risk and the benefits of international portfolio diversification. Journal of International Business Studies, 26: 301-318.

Dean T.J., Brown R.L., Bamford C.E. (1998) Differences in large and small firm responses to environmental context: Strategic implications from a comparative analysis of business formations. Strategic Management Journal 19: 709-728

Duanmu, J-L. (2012). Firm heterogeneity and location choice of Chinese Multinational Enterprises (MNEs). Journal of World Business, 47: 64-72.

Dunning, J. H., and Rugman, A. M. (1985). The Influence of Hymer Dissertation on the Theory of Foreign Direct-Investment. American Economic Review 75, 228-232.

Dunning, J.H. (1993) Multinational enterprise and the global economy. England: Addison-Wesley Publishers. 
Dunning J.H. (1998). Location of multinational enterprise: a neglected factor? Journal of International Business Studies, 29(1): 45-66.

Dunning (2000). The eclectic paradigm as an envelope for economic and business theories of MNE activity. International Business Review, 9: 163-190.

Dunning, J.H. (2001). The eclectic (OLI) paradigm of international production: past, present and future. International Journal of the Economics of Business, 8(2): 173-190.

Dunning, J.H. , Pak, Y.S. and Beldona, S. (2007). Foreign ownership strategies of UK and US international franchisors: an exploratory application of Dunning’s envelope paradigm. International Business Review, 16: 531-548.

Ekholm, K., Forslid, R., and Markusen, J. R. (2007). Export-platform foreign direct investment. Journal of the European Economic Association 5, 776-795.

Fratianni, M. and Hoon Oh, C. (2009). Expanding RTAs, trades flows, and the multinational enterprise. Journal of International Business Studies, 40: 1206-1277.

Greene, W. (2012). NLOGIT Version 5 Reference Guide. Econometric Software, Inc.

Head K., Ries J. (2008) FDI as an outcome of the market for corporate control: Theory and evidence. Journal of International Economics 74(1): 2-20

Helpman, E. (1984). A Simple Theory of International-Trade with Multinational-Corporations. Journal of Political Economy 92, 451-471.

Helpman, E., Melitz, M. J., and Yeaple, S. R. (2004). Export versus FDI with heterogeneous firms. American Economic Review 94, 300-316.Hennart, J-F. and Slangen, A.H.J. (2014). Yes, we really do need more entry mode studies! A commentary on Shaver, Journal of International Business Studies, 46: 114-122.

Hymer, S. H. (1976). "The International Operations of National Firms: A Study of Direct Foreign Investment (1960)," MIT Press, Cambridge.

Javorcik, B.S. (2004). The composition of foreign direct investment and protection of intellectual property rights: Evidence from transition economies. European Economic Review, 48(1): 3962. 
Jindra, B., Hassan, S.S. and Cantner, U. (2016). What does location choice reveal about knowledgeseeking strategies of emerging market multinationals in the EU? International Business Review, 25: 204-220.

Kogut, B. and Singh, H. (1988). The effect of national culture on choice of entry mode. Journal of International Business Studies, 19(3): 411-432.

Laamanen, T., Simula, T. and Torstila, S. (2012). Cross-border relocations of headquarters in Europe, Journal of International Business Studies, 43: 187-210.

Markusen, J. R. (1984). Multinationals, multi-plant economies, and the gains from trade. Journal of International Economics 16, 205-226.

Markusen, J. R. (1997). Trade versus Investment Liberalization, NBER Working Paper Series, Working Paper 6231.

Markusen, J. R., and Maskus, K. E. (2002). Discriminating Among Alternative Theories of the Multinational Enterprise, Journal of International Economics 10, 694-707.

Midelfart-Knarvik K.H., Overman H.G., Redding S.J., Venables A.J. (2000) The Location of European Industry. European Economy - Economic Papers 142, Commission of the EC, Directorate-General for Economic and Financial Affairs (DG ECFIN).

Nebus, J., and Chai, K. H. (2014). Putting the “psychic”' back in psychic distance: Awareness, perceptions, and understanding as dimensions of psychic distance. Journal of International Management, 20(1): 8-24.

Nocke V., and Yeaple S. (2007). Cross-border mergers and acquisitions vs. greenfield foreign direct investment: The role of firm heterogeneity. Journal of International Economics, 72(2): 336365.

Ojala, A. (2015). Geographic, cultural, and psychic distance to foreign markets in the context of small and new ventures. International Business Review, 24: 825-835.

Oviatt, B., and McDougall, P. (1994). Toward a theory of international new ventures. Journal of International Business Studies, 25(1): 45-64. 
Rasciute, S., Pentecost, E., and Ferrett, B. (2014a). Firm heterogeneity in modelling foreign direct investment location decisions. Applied Economics, 46(12), 1350-1360.

Rasciute, S, Puckett, S, Pentecost, EJ, Pentecost, EJ (2014b) The allocation of oecd direct investment between ceecs: A discrete choice approach, Bulletin of Economic Research, ISSN: 0307-3378.

Sethi, D., Guisinger, S.E., Phelan, S.E. and Berg, D.M. (2003). Trends in foreign direct investment flows: a theoretical and empirical analysis. Journal of International Business Studies (2003), 34, 315-326.

Sun, S.L., Peng, M.W., Ren, B. and Yan, D. (2012). A comparative ownership advantage framework for cross-border M\&As: the rise of Chinese and Indian MNEs. Journal of World Business, 47: 4-16.

Teece, D.J., Pisano, G. and Shuen, A. (1997). Dynamic capabilities and strategic management. Strategic Management Journal, 18(7): 509-533.

Woo C.Y. (1987) Path-Analysis of the Relationship between Market Share, Business-Level Conduct and Risk. Strategic Management Journal 8: 149-168. 